Green New Deal: policies to stop climate damage by 2025

Dr Ewan McGaughey ${ }^{1}$

This document contains concrete legal policies, to build upon statements of principle, to stop climate damage by 2025 . It is a model 'Green New Deal' that can be readily adopted by UK local and national governments, in the European Union, and in international law.

The five main sources of greenhouse gas emissions are,

- (1) Transport: buses, taxis, delivery vehicles, cars, trains, boats, planes

- (2) Energy generation: electricity and gas

- (3) Fossil fuel extraction: oil, gas, coal

- (4) Agriculture and food: farming, forestry (eg failing to draw down carbon) and supermarkets

- (5) Buildings

UK greenhouse gas emissions 1990-2017

Source: DBEIS, 2017 UK greenhouse gas emissions: final figures - data tables (2019) Table 3

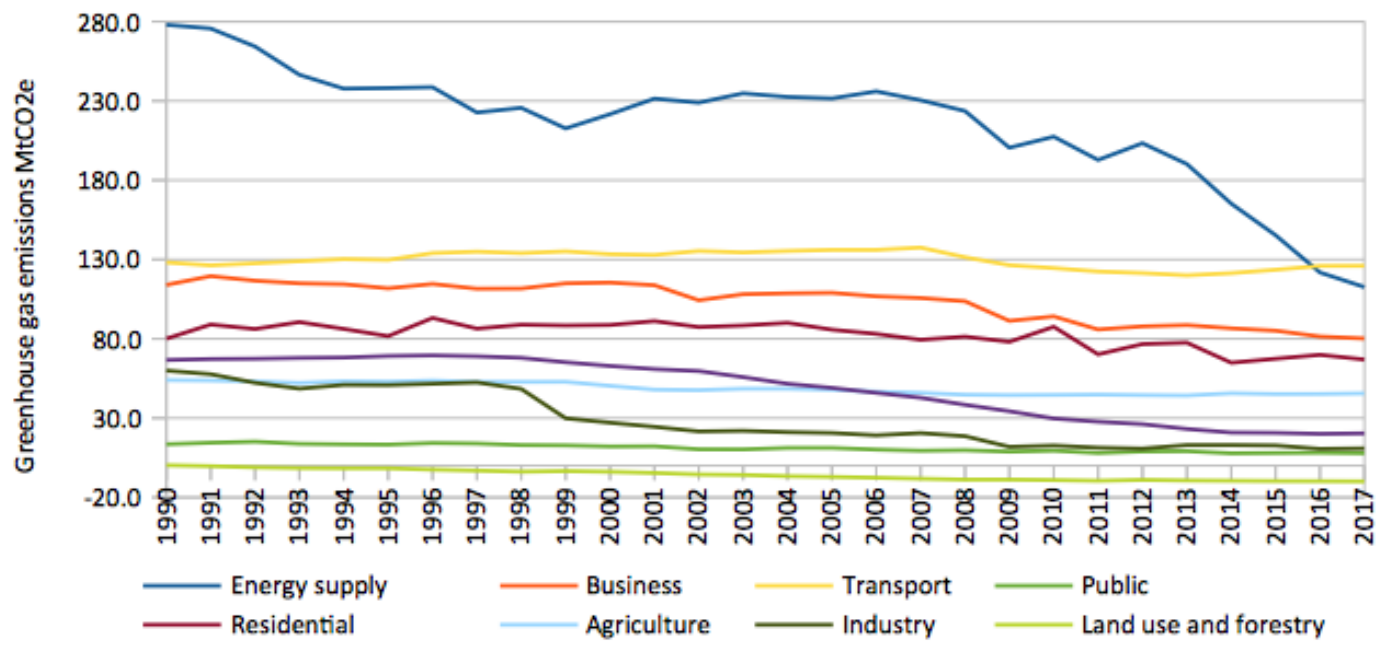

Sixth, an interrelated set of policy defects, perpetuating fossil fuels and climate damage, are,

- Corporate and bank governance

- Financial accounting and statistical collection

- Trade

Further measures could be added (and are likely necessary) to draw down carbon emissions, to reverse the climate damage already caused, and to punish those who have been enriched by the damage they have caused. It categorises measures according to action that can be taken now by local governments, national governments, and international bodies (particularly the European Union, World Bank, International Monetary, World Trade Organisation and United Nations). Measures are grouped by numbers (1)-(5), corresponding to the sector to which they relate, while number (6) encompasses corporate, financial, statistical and trade measures.

A few central facts are useful to understand the order of priority, and the relative ease (given rudimentary political will, and information) by which the economy can be decarbonised. These include the following:

- Buses, taxis and delivery vehicles compose $56 \%$ of exhaust pipe emissions in the UK. There are just 6.8 million such vehicles on the roads, compared to 31.4 million passenger cars. This

1 Senior Lecturer, School of Law, King's College, London. Research Associate, Centre for Business Research, University of Cambridge. Please contact at ewan.mcgaughey@kcl.ac.uk or @ewanmcg. This document results from a collective discussion, and many people's contributions of ideas, but I am especially grateful for discussion and comments from Laura Bear, Jason Hickel, Liv Jores, Alan Simpson, Ania Zbyszewska, Laura Mai, Henry Leveson-Gower, Fergus Green, Thomas Piketty, Grace Blakeley, Steve Daly, Tim Ashton, and Declan Kuch. 
makes dramatic emission reduction possible by starting with 'working' vehicles. These are easier to change than consumer behaviour, which will be most influenced by supply.

- Two of the top-20 global vehicle manufacturers from China (Changan and BAIC) have already committed to producing $100 \%$ electric vehicles by 2025 , while two others (Geely and Great Wall) have 50\% and 33\% pledges. This strongly suggests that if UK and EU manufacturers are not swiftly moved by regulation, they will be outcompeted.

- The Moray East wind farm is costing 2.6 billion to build, and provides enough electricity for just under 1 million homes. There are currently 27 million homes in the UK, and onethird of electricity is already renewable. This means a rough investment figure of $f, 46.8$ billion would electrify the remaining 18 million UK homes: that is $£ 9.2$ billion a year for 5 years. The same 18 million homes are currently spending about 10.6 billion a year on electricity bills. The big-six energy companies make around $f 4$ billion in profit each year. Thus, decarbonisation is publicly profitable in the short to medium term.

- Fossil fuel companies, in oil, gas and coal, have already been consistently under-performing the markets, and since 2016 have been the second-to-last performing sector in the S\&P 500. Their elimination from the global economy will not cause a crash as investors diversify, divest, and benefit from the upsurge in renewable business.

- Agricultural policy (in the EU, US or elsewhere) often receives less focus than it deserves because as a regulatory field it has often seemed opaque. Simple switches in rules for agricultural subsidies can restore the natural environment beyond recognition.

- Just 90 corporate entities are responsible for $63 \%$ of all historical greenhouse gas emissions.

Responsibility for, and the monetary enrichment through, climate damage is highly concentrated. This means focused and firm regulation will produce dramatic change.

\section{Local government}

The following are immediate steps that any local government could take to eliminate carbon emissions, so far as the council is capable. In the UK, councils have powers set out under the Local Government Act 1972, while devolved administrations have powers found in the Greater London Authority Act 1999, the Scotland Act 1998, and the Government of Wales Act 2006.

(1) Transport

(a) Set up an Ultra Low Emissions Zone in the centre of cities and towns, which phase out exhaust pipe emissions on all vehicles by 2025. As a minimum this should require that only vehicles meeting the Euro 4 standard enter towns by the end of 2021, only Euro 5 vehicles by 2022, only Euro 6 vehicles by 2023, and only 'Euro 7' vehicles (see 3(1)(a)) by the end of 2024 . Charges should be designed to encourage rapid switching in vehicles.

(b) Require that all new taxis, buses, or vehicles from public procurement contracts, used in the local authority (whether private or public) have zero-exhaust pipe emissions.

(c) Local authorities must only buy new vehicles that have zero exhaust pipe emissions.

(d) Fund cycling initiatives, to progressively increase the cycling rates in the locality to the average in Denmark or the Netherlands.

(e) Restore bus routes (outside London) to post-war levels of ridership in order to reduce reliance on cars, after councils regain power over bus networks (see section 2(1)(c)).

(2) Energy generation

(a) Use at least $50 \%$ of City Deal and Growth Deal money from central government to buy local energy generation facilities. This should be used for local government buildings, and transport.

(b) Establish a local government energy company (along the lines of Nottingham's Robin Hood Energy) which delivers 100\% renewable energy to residents (without paying shareholders). 
(3) Fossil fuel extraction

(a) Refuse planning permission for any form of fossil fuel extraction, and further (should planning have been granted by central government) to any buildings or construction that are associated with fossil fuel extraction business.

(4) Agriculture

(a) Make all agricultural planning permission contingent upon re-wilding all land that is not actively selling produce, after reform of planning laws (see section 3(4)(b)).

(5) Buildings

(a) Make all planning permission contingent upon having surplus energy generation, both for the building's use, and for associated vehicles.

(b) Audit all highways or streets in the locality, to designate a maximum number for elimination of cars, and reclamation for green spaces.

(6) Corporate, finance and trade

(a) Require that all Local Government Pension Funds divest from fossil fuels. (This is necessary to ensure that funds have no monetary incentive to continue supporting fossil fuel use in other investments: for instance, by failing to tell a vehicle manufacturer to switch to electric, because the fund has shares in oil and gas companies.)

\section{National government}

The following are measures that can be taken by Parliament, or potentially by the executive without an Act of Parliament.

(1) Transport

(a) Abolish all tax deductions for business vehicles which do not have zero exhaust pipe emissions, by amending the Capital Allowances Act 2001 section 104AA(4).

(b) Require that all new regulated vehicles are electric (taxis, buses, trains, and post vans) whether operated by public or private owners.

(c) Reverse the ban on council ownership of bus networks and regulation in the Bus Services Act 2017 section 22, to restore public transport journeys, with rules like the Greater London Authority Act 1999 sections 156, 174 and 180 (exclusive power to run buses and regulate fares).

Bus passenger journeys, 1970-2017

Source: DfT, Annual bus statistics, year ending: March 2018 tables, Bus0103 and 0108

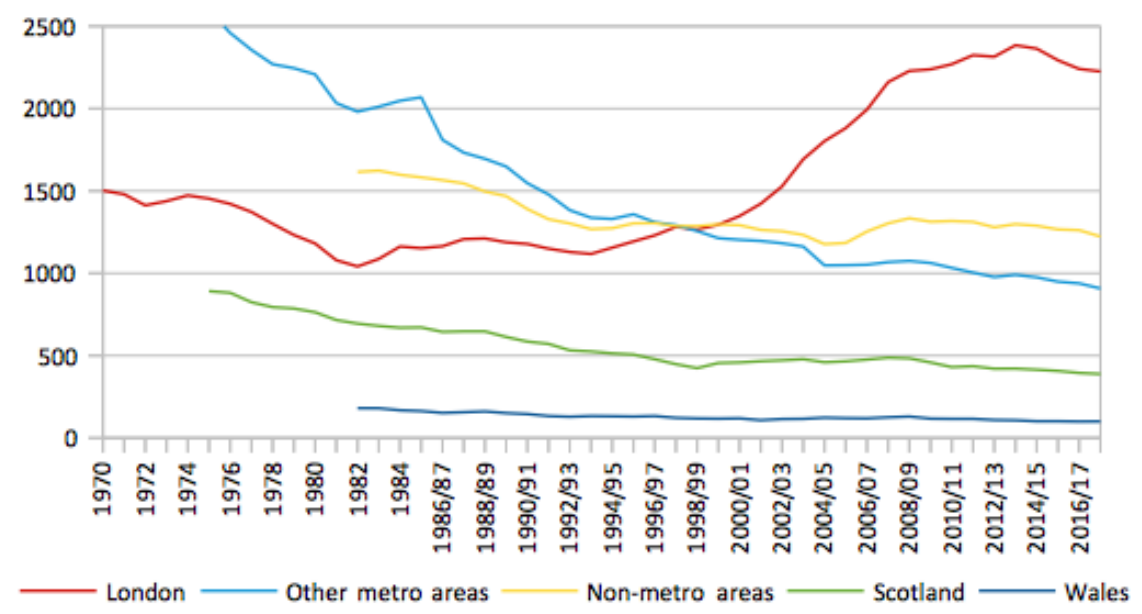


(d) Amend the Railways Act 1993 to require that all train companies electrify their rolling stock and Network Rail electrifies railway lines by 2025 , with thresholds of $60 \%$ by $2021,70 \%$ by $2022,80 \%$ by $2023,90 \%$ by 2024 , and $100 \%$ by 2025 .

(e) Remove the prohibition in the Railways Act 1993 section 25 on the UK and local governments taking railways into public ownership.

(f) Empower UK Government Investments to take a strategic stake of 5 to $25 \%$, after due diligence, in vehicle manufacturer company shares (wherever located) with the objective of bringing governance proposals to rapidly decarbonise production. Use voting power to block all proposals which are not coupled with a rapid decarbonisation plan.

(g) Under the Automated and Electric Vehicles Act 2018 section 11 require that all petrol stations within one year, and all car parks within three years according to their size introduce electric charging points.

(2) Energy generation

(a) Reverse the $9-10 \%$ corporation tax cuts since 2010 , to generate around $£ 30$ billion a year (, 150 billion in five years) and spend on generation of solar and wind energy on public land (including schools, hospitals, council buildings) with battery storage. Also use part for state aid to small and medium size enterprises in adopting electric vehicles (section 2(1)(a)-(b)), and for farmers that re-wild their land (section 2(4)(b)).

(b) Reverse the ban on onshore wind-farms, either for socially owned generation, or entirely.

(c) Restore the feed-in-tariff in the Electricity Act 1989 section $41 \mathrm{ff}$ for solar, wind or renewable production, mandating that energy companies pay all generators their market price minus a reasonable return of no more than $8 \%$.

(d) Restore renewable obligations on energy companies (scrapping 'Contracts for Difference') to include both electricity and gas, and mandate that energy companies fully decarbonise electricity, and electrify all gas water and heating systems by 2025: $20 \%$ reduction of emissions by the end of $2020,40 \%$ by $2021,60 \%$ by $2022,80 \%$ by 2023 , and $100 \%$ by the end of 2024 .

(3) Fossil fuel extraction

(a) Abolish the Infrastructure Act 2015 section 41 and Petroleum Act 1998 section 9A requiring the 'maximising of economic recovery of UK petroleum' and replace this with a duty to phase out all production consistent with redeploying workers into alternative jobs, with training, and with an equivalent income guarantee, by no later than 2022 .

(b) In advance of phasing out, reverse the cut in the Petroleum Revenue Tax from 50\% in 2010 to $0 \%$, now found in the Finance Act 2016 s 140(1).

(c) Pass a new Act of Parliament requiring that petroleum company shareholders and directors are personally liable for any unfulfilled costs of decommissioning oil rigs: see BBC News ( $\underline{21}$ November 2016).

(d) Prohibit all advertising of fossil fuel products (like the ban on tobacco advertising), including petroleum (e.g. BP and Shell), plastic (e.g. Coca Cola), gas (e.g. Gazprom), coal, or any fossil fuel based transport, by amending the Communications Act 2003 section 321.

(e) Amend the Communications Act 2003 section 319 to prohibit media organisations which promote the interests of fossil fuel states in supporting climate damage denial, such as RT and Sputnik, and apply this prohibition across all major internet advertising and media servers, including Youtube (and other Alphabet or Google services), Facebook, and Twitter.

(4) Agriculture and food

(a) Pass a new Anti-Enclosure Act 2019 to develop a new forestry and wildlife strategy that progressively takes derelict or un-utilised private land into social ownership, and expands nature reserves. 
(b) Amend the Town and Country Planning Act 1990 section 55(2)(e), which currently requires no planning permission for agricultural or forestry development, to empower local government to place conditions on agriculture and forestry use to re-wild a minimum percentage of lend, as set by the Secretary of State (see also section 3(4)).

(c) Amend the Food Standards Act 1999 section 6 to require that all food products, alongside an ingredients list, carry a traffic light code (green - amber - red) for the relative greenhouse gas impact of the good in manufacture and transportation, and also for health and nutritional value, as set by the Secretary of State in consultation with the Food Standards Agency. Place a duty on supermarkets to display the colour of carbon rating next to the price on each shelf.

(d) Require that the Food Standards Agency prohibit the use of plastic food packaging, including 'long use' plastic bags, by 2021, unless exceptions are granted based upon strict necessity, where no alternative exists.

(e) Introduce a general recyclability duty on supermarkets, so that all packaging is recyclable in that local authority, and that the supermarket repays a deposit fee for all bottles and cans.

(5) Buildings

(a) Place an obligation on all construction companies to certify that buildings generate all the energy they use, as well as associated vehicles.

(6) Corporate, finance and trade

(a) Make explicit the duty upon company directors to invest in renewable energy whenever it would eliminate energy bills in the long-term, and save vehicle running costs in the long-term, under the Companies Act 2006 section 174.

(b) Amend the UK Corporate Governance Code 2019 to require that every board has an environmental committee that develops a 3 year decarbonisation and divestment strategy.

(c) Establish an Investment Bank which lends at the Bank of England base rate to anyone who on approval invests in renewable energy infrastructure.

(d) Amend the Bank of England Act 1998 section 11 (objectives of the Bank in monetary policy) to prioritise environmental sustainability, decarbonisation, full employment on fair wages and reduced working time, and consumer price (including housing price) stability, and subject to that support the government's economic objectives.

(e) Require that the Treasury switches from GDP generation of accounts to a new Genuine Progress Indicator in 2020, based upon the concept of human and environmental well-being.

(f) Amend the Trustee Act 2000, the Pensions Act 1995, the Financial Services and Markets Act 2000 and all other related statutes to require that all pension funds, collective investment schemes, insurance companies, and other asset managers divest from fossil fuel stocks (in oil, gas and coal), and develop in their Statement of Investment Principles provisions on engagement with all other companies to eliminate greenhouse gases in their production and products.

(g) Activate and amend the Pensions Act 2004 sections 241-243 to require that all pension, retirement and mutual savings funds, whether in trust, corporate, contractual or other legal form, have at least one-half member-nominated trustees, either elected or nominated through a transparent and accountable process of the recognised trade union.

(h) Insert in the Financial Services and Markets Act 2000 a new section 241A to require that no collective investment scheme or other asset manager shall cast votes upon share capital it possesses without express voting instructions from its clients, and that there is a duty to follow such instructions free of charge.

(i) Explicitly codify duties in tort law, and criminal law, to not participate in climate damage. Codify the personal and punitive nature of liability for executives of all companies with disproportionate responsibility for greenhouse gas emissions. This should make clear that any person who negligently, recklessly or intentionally participates in action which causes damage to 
property, or people's safety, through the production of fossil fuels and/or greenhouse gases is liable to both compensate for all resulting losses, and to be punished to the extent that the tort is 'calculated to make a profit' (Rookes v Barnard [1964] UKHL 1). Criminal liability is appropriate for all subjectively reckless and intentional conduct.

(j) Amend the Competition Act 1998 section 3 to exempt all agreements between companies or other undertakings from the competition rules which agree to cooperate to eliminate greenhouse gas emissions.

(k) Restore collective bargaining on a sectoral basis, guarantee full employment under a new Ministry of Labour, and guarantee workers' rights in corporate governance, according to Rolling out the Manifesto for Labour Law (2018) and progressively reduce the working week, according to the European Social Charter 1966 article 2(1).

(l) Pass a new Economic Democracy Act 2019 that requires that in all public services, regulated enterprises, or other services of a general economic interest (e.g. water, energy, banks, supermarkets), that the public (in addition to workers, section $2(6)(\mathrm{k})$ ) has a minimum percentage of voting rights for members of the board of the enterprise.

(m) Amend the Consumer Rights Act 2015 sections 9, 19 and 23 (on consumer rights to satisfactory quality and repair) to create a right to products of 'lasting and durable quality', and to repair when within a statutory warranty, reflecting the limits of technical feasibility. Default periods should be set in codes of practice set by the Competition and Markets Authority in consultation with consumer rights groups.

\section{European Union}

The EU, probably more than China and the US, has the greatest capacity to shift the global economy to decarbonisation. Its powers are primarily set out in the Treaty on the Functioning of the European Union, and it can legislate through Directives, Regulations, or make soft law (where it cannot legislate) through Commission Recommendations.

(1) Transport

(a) A new Euro 7 emission standard should in 2019 allow only levels of CO, NOx and PM consistent with zero exhaust pipe emissions on passenger vehicles (i.e. fully electric or hydrogen vehicles). For heavy goods vehicles, the Euro 7 standard should be set at the optimum level enabled by technology: Vehicle Emissions Regulation 459/2012/EC Annex.

(b) A new EU Directive should enable member states or regional states to create golden shares in any automotive manufacturing company for the purpose of exercising governance and voting rights to rapidly decarbonise, in effect reversing Commission v Germany (2007) C-112/05.

(c) Amend the Railways Directive 2012/34/EC to require investment in high speed infrastructure and $100 \%$ electrification by 2025 .

(d) Subsidise railway routes that currently mirror plane routes and prohibit all plane flights where there is an alternative that is the same total travel time. Expressly empower member states to set stricter standards.

(e) Require member states to spend at least $0.5 \%$ of GDP in state aid or public investment for shifting to renewable delivery vehicles, taxis, buses, rail and consumer vehicles.

(f) Amend the Emission Performance Regulation (EC) 443/2009 article 1 to require that all vehicles manufactured are fully electric, or that no dividends or director compensation may be paid from 25 December 2021, and that accumulating fines up to $10 \%$ of turnover must be paid.

(2) Energy generation

(a) Amend the Electricity Directive 2009/72/EC to require full decarbonisation of electricity generation by $2025: 20 \%$ reduction of emissions by the end of $2020,40 \%$ by $2021,60 \%$ by 2022 , $80 \%$ by 2023 , and $100 \%$ by end of 2024 . 
(b) Set binding targets for the elimination of gas distribution in the Gas Directive 2009/73/EC, and the electrification or geothermalisation of building heating systems, according to the Electricity Directive schedule above.

(c) Require member states to spend at least $0.5 \%$ of GDP in state aid or public investment for business and residential generation of solar and wind energy, and battery storage, until decarbonisation is completed.

(3) Fossil fuel extraction

(a) Prohibit all extraction of oil, gas, and coal by EU companies anywhere in the world, and the listing of any such companies on any EU stock exchange.

(b) Require in all bilateral trade agreements that countries set a decarbonisation schedule, proportionate to the Paris Agreement 2015. This should be enforceable (as opposed to Investor State Dispute Settlement) by citizens or representative groups in arbitration procedures. Arbitration reasoning and awards should take no more than 6 months, and be made public.

(c) Enact a $€ 100$ per tonne tax on carbon emission producers, escalating yearly by $€ 100$ to 2025 , allocated to a Carbon Elimination Fund that pays for research and sustainable infrastructure.

\section{(4) Agriculture and food}

(a) Amend the Common Agricultural Policy Regulation 1307/2013 article 46 to require that all farmers with over 1 hectare (not 15 hectares) maintain 20 to $50 \%$ of land (not $5 \%$ of land) as an ecological focus area, in accordance with member state policy, so as re-wild the countryside with forests, peat bogs, and living meadows.

(b) Reorganise CAP Regulation 1307/2013 article 32 payments, so as to prioritise carbon reducing land-uses, including soil, tilling and fertilisation practices that retain carbon.

(c) Amend CAP Regulation 1307/2013 articles 10-11 and related annexes to phase out subsidies for farms receiving payments over $€ 150,000$ upon the completion of rewilding in 2030 .

(d) Introduce a new Supermarkets Directive 2019, applying to supermarket entities over a certain size, requiring (i) carbon and nutrition traffic light labelling on all food and products, (ii) a general recyclability duty for all products, (iii) supermarkets take back all glassware and metal for a deposit, (iv) decarbonisation of all vehicles, (v) a duty to ensure all agricultural producers and workers receive a living wage set through collective agreement, (vi) that all duties are enforceable by derivative claims by shareholders, employees, workers in supply chains, representative environmental groups, and the relevant member state regulator.

(5) Buildings

(a) Use the open method of coordination to draft best practices in Commission Recommendations on building standards, and green streetscapes.

(6) Corporate, finance and trade

(a) Switch from GDP generation of accounts to a Genuine Progress Indicator in 2020, and develop an EU concept of well-being that subtracts all contract values which generate ecological, health, or security-based harm, or which records disproportionate spending on privatised or government services, compared to the average of the top- 5 member states' accounts.

(b) Enact a new Regulation to clarify that the European Central Bank, in accordance with the 'primary objective... to maintain price stability' under TFEU article 282, must act subject to the overriding goals of the European Union under TEU article 3(3) to achieve (among other things) 'full employment and social progress, and a high level of protection and improvement of the quality of the environment.' Clarify that in the event of a conflict, the objective of price stability is subordinate to the goals in general of environmental improvement, full employment and social progress, and decarbonisation in particular. 
(c) Amend the Accounting Directive 2013/34/EU article 6 to require that all companies (including insurance firms, banks, and accounts) account for the full clean up costs resulting from climate damage, fossil fuel pollution, and all prospective climate-related risks.

(d) Amend the Shareholder Rights Directive 2007/36/EC article 10 to prohibit asset management firms, banks or any other form of financial intermediary from casting shareholder voting rights without specific instructions from an investor, or elected representative of an investor, in any company. All instructions must be followed. Pension funds must also have a duty to develop a voting policy on decarbonisation and environmental sustainability.

(e) Amend the General Company Law Directive 2017/1132 article 45 to require that any company holding fossil fuel assets must set aside an amount of reserve capital, that is calculated to cover the social and environmental costs of its usage. The Commission can make specific, temporary exemptions.

(f) Amend the Institutions for Occupational Retirement Provision Directive 2016/2341/EU article 21, the Undertakings for Collective Investment in Transferable Securities 2009/65/EC, the Alternative Investment Fund Managers Directive 2011/61/EU, and the Markets in Financial Instruments Directive 2014/65/EU to require that all investment funds divest fully from fossil fuel investments (coal, oil and gas) wherever located, and in their statements of investment principles require of all portfolio companies that a 3 year decarbonisation is put into effect.

(g) Pass a new Environmental Cooperation Directive 2019 to explicitly exempt all agreements from the competition rules in the Treaty on the Functioning of the European Union, under article 101(3), when they are designed to eliminate greenhouse gas emissions.

(h) Pass a new Global Marshall Plan Directive 2019 requiring that each member state contributes $0.5 \%$ of GDP to a common European fund that is used to fund infrastructure or at-cost-loans in global south countries for sustainable transport, energy generation and agricultural infrastructure.

\section{IMF, World Bank, WTO and UN}

Globally, the main international institutions include the International Monetary Fund, the World Bank, the World Trade Organisation, and the United Nations. While international consensus is notoriously slow, concerted pressure from the EU could bring significant shifts.

(1) Transport

(a) In all IMF structural adjustment policies, and as a condition for all World Bank grants, require that transport systems are decarbonised. No loan or fund must be used for fossil fuel vehicles.

(b) A system of binding quotas should be set for any loan or grant given by the IMF or World Bank, which requires decarbonisation by 2025.

(c) The World Bank should fund strategic infrastructure projects across the global south, particularly high-speed railways (to replace planes and fossil fuel vehicles) through South and Central America, from South to North Africa, and in East to West Africa, starting on existing or disused routes. With improvement, flight paths are to be progressively prohibited.

(d) Amend the International Convention for the Prevention of Pollution from Ships to require that corporations with over 15 twenty-foot equivalent unit capacity ships must decarbonise fleets to technological limits: $20 \%$ by $2021,40 \%$ by $2022,60 \%$ by $2023,80 \%$ by $2024,100 \%$ by 2025 .

(e) Since military organisations are the biggest consumers of oil, reaffirm the duty for peaceful settlement of disputes and the prohibition on war in the United Nations Charter 1945, article 2.

(2) Energy generation

(a) The World Bank should fund and the International Monetary Fund should grant interest-free loans for the development of renewable energy generation across the global south. 
(3) Fossil fuel extraction

(a) The Rome Statute article 7(1)(k) for the International Criminal Court, on 'crimes against humanity' should be amended to expressly codify the crime of intentionally extracting fossil fuels with a view to making a profit from their combustion, with the consequence of a foreseeable and significant contribution (measured in megatons) to climate damage.

(6) Corporate, finance, trade

(a) Shift from statistical collection by the World Bank, IMF, UN and all other agencies based on Gross Domestic Product to a new concept modelled on the Genuine Progress Indicator that prioritises well-being, and discounts damaging practices including environmental degradation, over-securitisation, health care failures, or other failures to produce public goods.

(b) Amend the General Agreement on Tariffs and Trade 1994 (the World Trade Organisation treaty) to enable trade sanctions against member states that fail to decarbonise their economies on a timescale proportionate to the Paris Agreement 2015.

(c) Amend the GATT 1994 to enable citizens and representative groups (as opposed to Investor State Dispute Settlement) to bring enforcement actions to the WTO Dispute Settlement Body against any member state or multinational investor for failure to decarbonise, according to the universal right to share in the benefits of science: Universal Declaration on Human Rights 1948 article 27(1) and the International Covenant on Economic, Social and Cultural Rights 1966 article 15(1)(b).

\section{Conclusions}

While these measures would assure rapid decarbonisation, a likely opposing argument is that they are too costly, or unachievable by 2025. In fact, almost all measures are free from cost, through simple changes of individual rules, and do not rely on taxation or spending. All investments by business will ensure long-run generation of revenue, with the exception that the fossil fuel industry will be entirely eliminated, and as soon as possible. Investments by government, particularly in transport and energy infrastructure will generate quantifiable and significant revenue. The exception of raising corporation tax, in the case of the UK, to the level it was at in 2010 generates approximately three times the $0.5 \%$ of GDP that can be used to fund transport, energy generation and global infrastructure. By comparison, the Marshall Plan in post-war Europe was itself $0.5 \%$ of US GDP. This triggered over two decades of prosperity.

The true costs exist in failing to act, through the daily, accumulating damage from fossil fuels. This is why far-off target dates of 2030, 2040 or 2050 that dominate environmental reform discourse are economically, socially, and politically inept. The costs of not acting now include,

- the extra deaths from toxic air pollution, which costs the National Health Service an estimated f6 billion every year, and kills 40,000 people a year, including children in their own classrooms

- the cost of subsidies to the fossil fuel industry, which in the UK alone is around 10.5 billion every year, and reaches a total of $€ 55$ billion across the EU

- the cost to people's health from wasteful, unhealthy food and supermarket practices, which in terms of obesity alone costs the NHS around f.6.1 billion every year

Every wisp of smoke from a truck, every puff from a power plant chimney, is doing us damage, even if we disregard the catastrophe of climate damage itself. Instead of acting now, targets of 2030, 2040 or 2050 kettle humanity into a greenhouse gas chamber of accumulating illness, and death, particularly for the young, and those in or about to enter into retirement. The claims of the fossil fuel industry, that their existence generates tax revenue, or that they provide energy security, are the opposite of reality. We can have a profitable fossil fuel industry, or we can have life on a living planet, but we cannot have both. Climate damage must end and fossil fuels must become extinct, so that we can live in a prosperous, free, clean and just society. 